\title{
Film Noir Reconfigured in the Essay-film 33, by Kiko Goifman
}

\author{
João L. P. Mologni*, Francisco E. Teixeira.
}

\begin{abstract}
This research takes into account the conjunction of two often polemic topics when dealing with cinema studies: the film noir and the essay-film. More specifically, the essay-film 33 (Kiko Goifman, 2002) and its use of noir aesthetics, form and themes in order to develop the process of (thinking of) meeting a biological mother. Through bibliographical research about the two kinds of films here described and analysis of the films 33, The Maltese Falcon (John Huston, 1941) and Murder, My Sweet (Edward Dmytryk, 1944), it is plausible to say the noir tropes are rekindled with a documentary-ish style akin to the cinéma vériteé, stating that, actually, there is no truth at all. The blurred boundaries between right or wrong in noirs give place to the blurred boundary between questions and answers in 33 .
\end{abstract}

\section{Key words:}

noir, essay-film, 33, Kiko Goifman.

\section{Introduction}

Despite the known controversies built around the film noir and the essay-film, this research focused on the socially present "noir genre", its aesthetics and forms, and the notion of the essay-film as a new domain of the cinema practice, in which the fictional, documentary and experimental domains are bundled up in a new form of imagery (TEIXEIRA, 2015).

Those subjects (the noir tropes and the essayfilm's nature) are brought up together in the film 33 (Kiko Goifman, 2002), going far beyond mere stylistic choice or kinship between film noir and Goifman's film subject matter. Moreover, the course of the theorizations made about the essay-film (TEIXEIRA, 2014; CORRIGAN, 2011; RASCAROLI, 2008) seem to relegate its fictional heritage, focusing primarily on its documentary and experimental relations.

33, however, with its clear homages to noir classics such as The Maltese Falcon (John Huston, 1941), brings up the need to consider more the power of the fictional domain within the lived experiences shown in every essay-film. This focus on the greater relationship that may exist between the fictional and the essay-film is what is at stake in this research, taking into account the films 33, The Maltese Falcon and Murder, My Sweet (Edward Dmytryk, 1944).

\section{Results and Discussion}

33 is about the filmmaker's own investigation about his biological mother in the course of 33 days, while he is 33 years old. It is never shown if Goifman actually met his mother, because this was never the purpose of the film. The focus was to show his process both the investigation and the preparation to meet the one who has brought him to life - through 33 days. It not only reflects the essay-film trope of displaying the processes of thought just like the literary essay, of making the film "a form that thinks", as Godard would say (TEIXEIRA, 2015), but also shows a similar noir trope of bringing to light how things happened instead of what happened (SCHRADER, 2003).

But, while film noirs always have a (not-sooptimistic) closure, revealing the destruction a double-led life will cause, 33 neglects a definite ending so as to sustain the mystery regarding his own family. The chiaroscuro lighting during the interviews represents the fragmentary and sometimes contradictory nature of memories, the people described in them and the very people telling them, too. A closure would mean bringing them to light, or relegating them to the darkness. As Laura Rascaroli (2009, p. 58-60) says, the filmmaker never gives answers to the spectator in an essay-film.

In this way, Goifman's biological mother is a latent femme fatale: meanwhile this character in the film noir trope is a seductive promise for a new life, only to be revealed as the personification of death (SPICER, 2002), in 33 the seductive idea of meeting his own mother motivates the film, but maybe its consequences may not go as well as expected. Getting to know his own mother would be the ending of the investigations and the questions presented not only to the spectators, but to Goifman himself as well; would be killing the whole movie and the artist with(in) it.

\section{Conclusions}

In conclusion, it can be seen that the use of a genre's imagery in a documentary-ish film may be read as an experimentation, but it also builds up a new meaning to the filmmaker's concerns about its own creation. Rescuing noir tropes and the significations they imply opens a new way of dealing with the personal and impersonal in essay-films, mostly because of the mass culture they represent (BERNARDET, 2000); but it also opens a new way of considering a genre's tropes as well, invigorating cinema itself, in all its territories, its domains.

\section{Acknowledgement}

I would like to thank the Serviço de Apoio ao Estudante (SAE/Unicamp) for granting me this scholarship.

BERNARDET, J. C. A Subjetividade e as Imagens Alheias: Ressignificação. In BARTUCCI, G. (Org.). Psicanálise, Cinema e Estéticas de Subjetivação. Rio de Janeiro: Imago, 2000

CORRIGAN, T. The Essay Film: from Montaigne, after Marker. New York: Oxford University Press, 2011 .

RASCAROLI, L. The Essay Film: Problems, Definitions and Textual Commitments. The Journal of Cinema and Media. Detroit, v. 49, n. 2, pp. 2447. 2008 .

SCHRADER, P. Notes on film Noir. In: GRANT, Barry Keith (Ed.). Film Genre Reader III. Austin: University of Texas Press, 2003. pp. 229-242.

SPICER, A. Film noir. Harlow: Longman, 2002.

TEIXEIRA, F. E. (Org.). O Ensaio no Cinema: formação de um quarto domínio das imagens na cultura audiovisual contemporânea. São Paulo: Hucitec, 2015. 